\title{
PERFORMA PENCAHAYAAN DAN PENGHAWAAN SERTA PERSEPSI PENGGUNA BANGUNAN PASAR DI KOTA PONTIANAK
}

\author{
Lestari \\ Program Studi Arsitektur, Fakultas Teknik, \\ Universitas Tanjungpura \\ lestari@teknik.untan.ac.id
}

\section{Ridha Alhamdani}

Program Studi Arsitektur, Fakultas Teknik,

Universitas Tanjungpura

mridhaalhamdani@gmail.com

\author{
Hamdil Khaliesh \\ Program Studi Arsitektur, Fakultas Teknik, \\ Universitas Tanjungpura \\ hamdiel.st@gmail.com
}

\begin{abstract}
Abstrak
Permasalahan yang ada pada pasar-pasar tradisional termasuk yang terjadi pada pasar Kemuning dan Dahlia Kota Pontianak dapat menggambarkan kualitas performansi bangunan. Pencahayaan, sirkulasi udara, dan temperatur dalam ruang pada bangunan merupakan aspek-aspek yang dapat mempengaruhi kenyamanan aktivitas pengguna. Tulisan ini memaparkan mengenai hasil penelitian khususnya mengenai tingkat pencahayaan, keadaan udara, dan temperatur dalam ruang pada dua pasar tradisional di Kota Pontianak tersebut. Performansi kedua pasar tersebut diukur untuk dibandingkan dengan standar untuk aktivitas yang sesuai. Selain itu dikumpulkan pula pendapat dari para pengguna tentang kepuasan terhadap aspek pencahayaan, keadaan udara, dan temperatur dalam ruang di kedua pasar tersebut. Data-data yang dikumpulkan melalui 2 cara yaitu observasi dan kuesioner. Observasi dilakukan dengan pengukuran pada bangunan. Kuesioner disebarkan kepada 195 responden khususnya penjual dan pembeli pasar untuk melihat tingkat kepuasan berdasarkan persepsi pengguna. Hasil analisis diperoleh bahwa tingkat performansi pencahayaan, keadaan udara, dan temperatur dalam ruang pada kedua bangunan pasar tersebut termasuk rendah, begitu pula kepuasan pengguna terhadap kedua aspek tersebut
\end{abstract}

Kata-kata Kunci: pasar tradisional, performasi bangunan, pencahayaan, penghawaan.

\section{THE PERFORMANCE OF LIGHTING, VENTILATION, AND USER PERCEPTION ON MARKET BUILDING IN PONTIANAK CITY}

\begin{abstract}
Problems that exist on traditional markets including those that occur in the Kemuning and Dahlia market, Pontianak City can represent the quality of building performance. Lighting, ventilating and air temperature in buildings are aspects that can affect the comfort of occupants. This paper describes the results of research especially regarding the level of lighting, ventilating and air temperature in two traditional markets at Pontianak City. The performance of both markets is compared to the standard for the appropriate activity. The user satisfaction is also identified. The data collected through 2 ways that are observation and questionnaire. Observations were made with measurements of buildings. Questionnaires were distributed among 195 respondents, especially sellers and market buyers to see the level of satisfaction based on user perceptions. The analysis
\end{abstract}


indicates performance levels of both market buildings are low, as are user satisfaction with those aspects.

Keywords: traditional market, building performance, lighting, ventilating, temperature

\section{Pendahuluan}

Pemerintah Kota Pontianak telah melaksanakan program penataan pasar tradisional agar bentuk, fungsi dan lingkungan pasar dapat meningkat kualitasnya. Program penataan pasar tradisional menjadi salah satu kebijakan Pemerintah Kota Pontianak untuk meningkatkan fungsi pasar tradisional dalam mendukung perekonomian rakyat. Pengukuran kondisi performansi bangunan dan dampaknya bagi pengguna dan lingkungannya, dapat memberikan nilai manfaat dalam upaya penataan pasar berikutnya sehingga permasalahan yang sama tidak menjadi permasalahan yang berulang. Pengukuran ini akan memberikan masukan dalam perencanaan sebagai upaya meningkatkan keberhasilan program penataan pasar serta masukan perbaikan kondisi yang ada. Permasalahan yang dianggap muncul pada pasar-pasar tradisional di Kota Pontianak masih berdasarkan pandangan visual dan belum dilakukan pengukuran secara spesifik terkait permasalahan tersebut. Permasalahan yang muncul dapat menggambarkan kualitas performansi bangunan baik secara fisik maupun fungsi. Dua pasar tradisional di Kota Pontianak yang selama ini dianggap memiliki banyak permasalahan adalah pasar Kemuning dan Dahlia. Selain berada dilahan yang sempit, kurang optimalnya penggunaan ruang-ruang pada bangunan pasar mengidentifikasikan adanya sebuah permasalahan yang perlu dikaji penyebab dan solusinya.

Permasalahan yang sering terjadi pada bangunan-bangunan pasar tradisional adalah kesan kumuh dan kotor yang muncul pada bangunan tersebut. Terbentuknya pasar dengan kesan kumuh dapat diakibatkan karena faktor tata persampahan yang kurang baik, dan pencemaran udara dari bau yang ditimbulkan akibat aktivitas pasar yang kurang tertangani dengan baik. Pencahayaan dan penghawaan yang kurang memadai juga merupakan faktor yang dapat memunculkan lingkungan pasar yang kumuh dan sehingga berpotensi menumbuhkan lingkungan pasar yang kurang sehat.

Tulisan ini memaparkan hasil penelitian yang bertujuan untuk melakukan pengukuran terhadap performa pencahayaan dan penghawaan bangunan pasar khususnya pasar tradisional Kemuning dan Dahlia yang ada di Kota Pontianak. Penelitian dibatasi pada aspek pencahayaan dan penghawaan di dua bangunan pasar tradisional tersebut. Performa bangunan merupakan suatu keadaan yang menggambarkan tingkat pencapaian hasil atau kinerja bangunan untuk memenuhi kebutuhan fungsi atau kepuasan dari pengguna. Performa dapat diukur atau dinilai dengan membandingkan keadaaan yang terjadi dengan standar atau ketentuan yang berlaku mengenai kinerja bangunan yang seharusnya terpenuhi. Standar atau ketentuan yang dipakai dapat berupa SNI atau ketentuan lain. Pengukuran dapat juga dilakukan dengan penggalian terhadap kepuasan pengguna sehingga dapat menggambarkan tingkat pencapaian kinerja dari persepsi pengguna. Hasil penelitian pengukuran terhadap performa pencahayaan dan penghawaan bangunan pasar khususnya pasar tradisional Kemuning dapat menggambarkan tingkat kualitas pencahayaan dan penghawaan pada pasar tradisional yang menjadi kasus, untuk dapat menjadi bahan masukan perbaikan kondisi yang ada dan pertimbangan bagi perancangan pasar-pasar tradisional berikutnya. 


\section{Kajian Pustaka \\ Pasar Tradisional}

Disebutkan dalam Standar Nasional Indonesia (SNI) 8152: 2015 Tentang Pasar Rakyat dan Undang-Undang Republik Indonesia Nomor 7 Tahun 2014 Tentang Perdagangan bahwa pasar adalah lembaga ekonomi tempat bertemunya pembeli dan penjual, baik secara langsung maupun tidak langsung, untuk melakukan transaksi perdagangan. Menurut Keputusan Menteri Perindustrian dan Perdagangan Nomor 23/MPP/KEP/1/1998 tentang Lembaga-Lembaga Usaha Perdagangan, pasar didefinisikan sebagai tempat bertemunya pihak penjual dan pembeli untuk melaksanakan transaksi di mana proses jual beli terbentuk. Sedangkan menurut Campbell (1990), dalam Sukriswanto (2012), pasar dapat didefinisikan sebagai institusi atau mekanisme di mana pembeli (yang membutuhkan) dan penjual (yang memproduksi) bertemu dan secara bersama-sama mengadakan pertukaran barang dan jasa.

Menurut Keputusan Menteri Perindustrian dan Perdagangan Nomor 23/MPP/KEP/1/1998, pasar dikelompokkan menurut kelas pelayanannya terbagi menjadi pasar tradisional dan pasar modern. Peraturan Menteri Perdagangan Republik Indonesia Nomor : 70/M-DAG/PER/12/2013 Tentang Pedoman Penataan dan Pembinaan Pasar Tradisional, Pusat Perbelanjaan dan Toko Modern menjelaskan bahwa pasar tradisional adalah pasar yang dibangun dan dikelola oleh Pemerintah, Pemerintah Daerah, Swasta, Badan Usaha Milik Negara dan Badan Usaha Milik Daerah termasuk kerjasama dengan swasta dengan tempat usaha berupa toko, kios, los dan tenda yang dimiliki atau dikelola oleh pedagang kecil, menengah, swadaya masyarakat atau koperasi dengan usaha kecil, modal kecil dan dengan proses jual beli barang dagangan melalui tawar menawar.

Berdasarkan pola manajemen yang dipakai, pasar dapat dikelompokkan menjadi dua kelompok besar yaitu :

- Pasar Tradisional adalah pasar yang masih memakai pola manajemen yang sederhana dengan ciri-ciri setiap pedagang mempunyai satu jenis usaha, adanya interaksi antara penjual dan pembeli (sistem tawar menawar)

- Pasar Modern adalah pasar yang sudah memakai pola manajemen modern dengan ciri-ciri jenis barang dagangan yang dilakukan oleh satu pedagang, harga tetap, tata letak barang dagangan rapi dan kenyamanan serta keamanan menjadi prioritas pelayanan.

Pasar tradisional dengan pengertian dan karakteristiknya cenderung menjadi pasar rakyat, yang dalam SNI 8152-2015 disebutkan sebagai pasar dengan lokasi tetap berupa sejumlah toko/kios, los dan bentuk lainnya dengan pengelolaan tertentu dan menjadi tempat jual beli dengan proses tawar menawar. Oleh karena itu standar bangunan pasar tradisional dapat mengacu pada Standar Nasional Indonesia (SNI) 8152-2015 mengenai Pasar Rakyat. Beberapa istilah ruang dagang yang digunakan dalam standar tersebut antara lain toko/kios, los dan jongko/konter/pelataran. Toko atau kios didefinisikan sebagai ruang dagang dengan dinding pemisah, los didefinisikan sebagai ruang dagang terbuka yang dapat dilengkapi dengan meja dan jongko/konter/pelataran didefinisikan sebagai ruang dagang yang bersifat temporer.

Untuk mencapai kenyamanan dalam bangunan beberapa aspek ditinjau dari segi kesehatan telah dijelaskan melalui Keputusan Menteri Kesehatan Republik Indonesia Nomor 1405/MENKES/SK/XI/2002 tentang Persyaratan Kesehatan Lingkungan Kerja Perkantoran dan Industri dan Keputusan Menteri Kesehatan Republik Indonesia Nomor 1405/MENKES/SK/XI/2002 . Kepeutusan tersebut dapat dijadikan acuan untuk melakukan penilaian terhadap performa pencahayaan pada bangunan pasar. Beberapa aspek kenyamanan dalam bangunan pada Keputusan Menteri tersebut terkait dengan masalah pencahayaan dalam bangunan, suhu dan kelembaban, dan tingkat kebisingan. 
Tabel 1. Tingkat Pencahayaan Lingkungan Kerja

\begin{tabular}{|c|c|c|}
\hline Jenis Kegiatan & $\begin{array}{c}\text { Tingkat } \\
\text { Pencahayaan } \\
\text { Minimal (lux) } \\
\end{array}$ & Keterangan \\
\hline $\begin{array}{l}\text { Pekerjaan kasar dan tidak terus - } \\
\text { menerus }\end{array}$ & 100 & 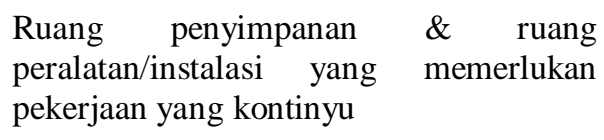 \\
\hline $\begin{array}{l}\text { Pekerjaan kasar dan terus - } \\
\text { menerus }\end{array}$ & 200 & $\begin{array}{l}\text { Pekerjaan dengan mesin dan perakitan } \\
\text { kasar }\end{array}$ \\
\hline Pekerjaan rutin & 300 & $\begin{array}{l}\text { Ruang administrasi, ruang kontrol, } \\
\text { pekerjaan mesin \& perakitan/penyusun }\end{array}$ \\
\hline Pekerjaan agak halus & 500 & $\begin{array}{l}\text { Pembuatan gambar atau bekerja dengan } \\
\text { mesin kantor, pekerjaan pemeriksaan atau } \\
\text { pekerjaan dengan mesin }\end{array}$ \\
\hline Pekerjaan halus & 1000 & $\begin{array}{l}\text { Pemilihan warna, pemrosesan teksti, } \\
\text { pekerjaan mesin halus \& perakitan halus }\end{array}$ \\
\hline Pekerjaan amat halus & $\begin{array}{l}1500 \\
\text { Tidak } \\
\text { menimbulkan } \\
\text { bayangan }\end{array}$ & $\begin{array}{l}\text { Mengukir dengan tangan, pemeriksaan } \\
\text { pekerjaan mesin dan perakitan yang } \\
\text { sangat halus }\end{array}$ \\
\hline Pekerjaan terinci & $\begin{array}{c}3000 \\
\text { Tidak } \\
\text { menimbulkan } \\
\text { bayangan }\end{array}$ & $\begin{array}{l}\text { Pemeriksaan pekerjaan, perakitan sangat } \\
\text { halus }\end{array}$ \\
\hline
\end{tabular}

\section{Sumber: KEPMENKES RI. No.1405/MENKES/SK/XI/02}

Tingkat pencahayaan yang disyaratkan dalam ruangan menurut Keputusan Menteri Kesehatan Republik Indonesia Nomor 1405/MENKES/SK/XI/2002 tersebut seperti yang jelaskan pada Tabel 1. Selain itu, untuk menunjang lingkungan pasar yang lebih bersih dan sehat serta mengantisipasi terbentuknya lingkungan pasar yang kumuh dan berpotensi menumbuhkan lingkungan tidak sehat, pemerintah mengeluarkan kebijakan melalui Keputusan Menteri Kesehatan Republik Indonesia Nomor : 519/MENKES/SK/VI/2008 tentang Pedoman Penyelenggaraan Pasar Sehat. Suhu dan kelembaban yang dipersyaratkan secara kesehatan menurut Keputusan Menteri Kesehatan Republik Indonesia Nomor 1405/MENKES/SK/XI/2002 adalah $18-28^{0} \mathrm{C}$ dengan kelembaban: $40 \%-60 \%$. Namun, persyaratan ini harus disesuaikan dengan standar fungsi dan kebutuhan ruang. Apabila tidak ditentukan dalam standar, secara umum menurut SNI 03-6390-2000 tentang konservasi energi sistem tata udara pada bangunan gedung harus digunakan kondisi perencanaan dengan temperatur bola kering $25^{\circ} \mathrm{C} 1{ }^{\circ} \mathrm{C}$ dan kelembaban relatif $60 \% \pm 10 \%$ untuk kenyamanan pengguna. Sedangkan menurut Karyono (2001), dengan mengacu pada pedoman ANSI/ASHRAE 55-1992, suhu nyaman $24^{\circ} \mathrm{C} \pm 2{ }^{\circ} \mathrm{C}$, atau rentang antara $22^{\circ} \mathrm{C}$ hingga $26^{\circ} \mathrm{C}$. Ketentuan dalam perencanaan sirkulasi udara menurut Peraturan Menteri Pekerjaan Umum Nomor: 29/Prt/M/2006 Tentang Pedoman Persyaratan Teknis Bangunan Gedung adalah jumlah bukaan ventilasi tidak kurang dari 5\% terhadap luas lantai ruangan yang membutuhkan ventilasi. 


\section{Metode Penelitian \\ Metode Pengumpulan Data}

Penelitian ini menggunakan 2 data yaitu data lapangan hasil observasi dan data kuesioner dari pendapat responden. Data lapangan diperoleh dengan cara observasi dan studi lapangan. Hal ini dilakukan melalui pengukuran dan dokumentasi terhadap kondisi bangunan. Data pengukuran lapangan diperoleh dengan menggunakan alat ukur luxmeter, termometer, hygrometer. Pada setiap bagian bangunan ditempatkan titik-titik pengukuran yang hasilnya kemudian dinilai berdasarkan acuan standar khususnya yang terkait dengan standar tentang kenyamanan gedung dan perancangan bangunan pasar. Standar yang digunakan mengacu pada Standar Nasional Indonesia (SNI) 8152 tahun 2015 tentang Pasar Rakyat, Keputusan Menteri Kesehatan Republik Indonesia Nomor 1405/MENKES/SK/XI/2002 tentang Persyaratan Kesehatan Lingkungan Kerja Perkantoran dan Industri, Kondisi bangunan melalui observasi lapangan dinilai berdasarkan kriteria penilaian rendah, sedang dan baik

Data yang kedua yang digunakan adalah data pendapat responden, berupa penggalian data dari pemakai yaitu pelaku pasar khususnya pedagang dan pembeli. Data ini diperoleh melalui kuesioner yang disebarkan kepada 195 pedagang dan pembeli di kedua pasar. Kuesioner di susun untuk melihat tingkat kepuasan pengguna melalui skala likert yang memiliki skala 1-7. Skala 1 menunjukkan "sangat tidak puas", skala 2 menunjukkan "tidak puas", skala 3 menunjukkan "kurang puas", skala 4 menunjukkan "antara cukup puas dan kurang puas", skala 5 menunjukkan "cukup puas", skala 6 menunjukkan "puas", skala 7 menunjukkan "sangat puas".

\section{Metode Analisis Data}

Data yang diperoleh baik melalui observasi maupun melalui kuesioner pendapat responden dianalisis secara kuantitatif. Hasil observasi dinyatakan dalam nilai performansi [NP] dan hasil dari penilaian kuesioner dinyatakan dalam Nilai Kepuasan Responden [NR]. Nilai performansi dinyatakan rendah jika nilainya $<0.5$, dinyatakan sedang jika jika nilainya $0.5 \leq \mathrm{NP}<0.6$, dinyatakan baik jika nilainya $0.6 \leq \mathrm{NP}<1$, dan dinyatakan sangat baik jika nilainya adalah 1 . Nilai performansi didapat dengan rumus:

$$
[\mathrm{NP}]=\underline{\text { Kategori Hasil Penilaian }}
$$

10

Nilai dari hasil kuesioner diperoleh untuk mendapatkan tingkat kepuasan dari pengguna terhadap bangunan yang dinyatakan dalam nilai kepuasan responden [NR]. Pengguna dikatakan tidak nyaman jika $[\mathrm{NR}]$ nilainya $<0.5$, netral jika $0.5 \leq \mathrm{NR}<0.6$, dan nyaman jika nilainya $\geq 0.6$. Nilai kepuasan Responden didapat dengan rumus :

$$
[N R]=\left[N^{1} \times 1\right]+\left[N R^{2} \times 2\right]+\left[N^{3} \times 3\right]+\left[N R^{4} \times 4\right]+\left[N R^{5} \times 5\right]+\left[N R^{6} \times 6\right]+\left[N R^{7} \times 7\right]
$$

Keterangan:

$[\mathrm{NR}]=$ nilai kepuasan responden

NR1, NR2, NR3, NR4, NR5, NR6, NR7= Jumlah responden dengan penilaian skala likert $1,2,3,4,5,6$, dan 7

Total $\mathrm{R}=$ Jumlah total responden

Hasil nilai [NR] yang didapatkan kemudian dilihat perbandingannya antara penilaian penjual dan penilaian pembeli sehingga dapat diperoleh kesimpulan nilai kepuasan dari kedua pengguna tersebut. 


\section{Hasil dan Pembahasan}

Kasus bangunan pasar dipilih adalah Pasar Dahlia dan Pasar Kemuning. Lokasi kedua pasar tersebut di Kota Pontianak dapat dilihat pada Gambar 1. Pertimbangan dalam pemilihan lokasi pasar tersebut adalah tingkat kompleksitas permasalahan dan tingkat keberhasilan dari bangunan pasar. Lokasi Pasar Kemuning berada di Jl. Prof. M. Yamin. Bangunan 2 lantai ini berupa los/meja jualan di bagian lantai 1 dan berupa kios-kios di bagian lantai 2. Lokasi Pasar Dahlia berada di jalan H. Rais A.Rahman. Bangunan yang terdiri dari 2 lantai ini juga memiliki los/meja di lantai 1 dan kios di lantai 1 dan lantai 2.

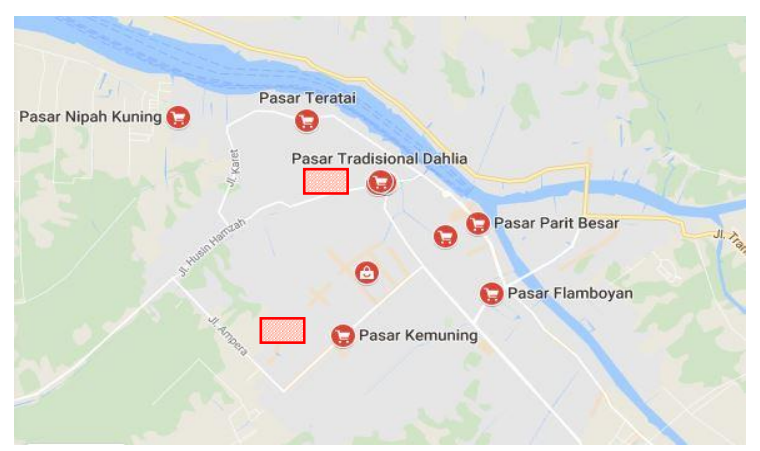

Gambar 1. Lokasi Penelitian Kedua Pasar

Sumber: https://www.google.co.id/maps yang dimodifikasi Penulis, 2017

Berdasarkan observasi yang dilakukan tingkat pencahayaan pada bangunan Pasar Kemuning cukup rendah performansi nya jika dibandingkan dengan persyataran standar yang telah ditetapkan. Kondisi yang terukur di pasar Kemuning, pencahayaan tidak merata pada bagian-bagian bangunan. Hasil pengukuran di bagian Penjualan lantai 1, pencahayaan mulai dari 22 lux sampai dengan 1464 lux. Nilai 22 lux sangat rendah dari persyaratan yang tetapkan yaitu mencapai 200-300 lux. Hasil pengukuran di bagian Penjualan lantai 2, pencahayaan dari 10 lux sampai dengan 4760 lux. Pencahayaan ini sangat tergantung letak los/kios. Los dan kios-kios yang berada di bagian tengah bangunan memiliki tingkat pencahayaan yang rendah, sedangkan los atau kios-kios yang berada di bagian sisi bangunan mendapatkan pencahayaan yang berlebih dari matahari. Kondisi temperatur dalam bangunan juga menunjukkan performa yang rendah karena berdasarkan pengukuran rata-rata temperatur dalam bangunan $32{ }^{\circ} \mathrm{C}$.

Hasil observasi yang dilakukan di Pasar Dahlia menunjukkan performansi yang tidak jauh berbeda dengan pasar Kemuning. Tingkat performansi pencahayaan pada bangunan Pasar Dahlia juga termasuk rendah dibandingkan persyaratan yang dibutuhkan. Kondisi yang terukur di pasar Dahlia, pencahayaan tidak merata pada bagian-bagian bangunan. Hasil pengukuran di bagian penjualan lantai 1 pencahayaan mulai dari 10 lux sampai dengan 2800 lux. Sedangkan di lantai 2 dari 10 lux sampai dengan 4000 lux, padahal standar untuk kegiatan yang sesuai pada aktivitas pasar mengharuskan pencahayaan pada 200-300 lux. Pencahayaan ini juga sangat tergantung letak los/kios. Los dan Kios-Kios yang berada di bagian tengah bangunan memiliki pencahayaan yang rendah, sedangkan los atau kios-kios yang berada di bagian sisi bangunan yang berhubungan langsung dengan bagian luar mendapatkan pencahayaan yang cukup, bahkan berlebih karena mendapat cahaya langsung dari matahari. Kondisi temperatur dalam bangunan menunjukkan ratarata temperatur $33{ }^{\circ} \mathrm{C}$. Padahal, nilai temperatur nyaman yang dipersyaratkan secara kesehatan menurut Menteri Kesehatan Republik Indonesia Nomor 1405/MENKES/SK/XI/2002 adalah 18 - 28

${ }^{0} \mathrm{C}$. Nilai performa [NP] ketiga aspek tersebut dapat dilihat pada Tabel 2 berikut: 
Tabel 2. Nilai Performansi

\begin{tabular}{|c|c|c|c|c|c|c|c|c|}
\hline \multirow{2}{*}{$\begin{array}{l}\text { Variabel } \\
\text { Aspek } \\
\text { bangunan }\end{array}$} & \multicolumn{5}{|c|}{ Kriteria Penilaian (Nilai) } & \multirow{2}{*}{$\begin{array}{c}\text { Kondisi Hasil } \\
\text { Observasi }\end{array}$} & \multirow{2}{*}{ Nilai } & \multirow{2}{*}[\mathrm{NP}]{} \\
\hline & $1-2$ & $3-4$ & $5-6$ & $7-8$ & $9-10$ & & & \\
\hline \multirow[t]{2}{*}{ Penghawaan } & \multirow[t]{2}{*}{$\begin{array}{l}\text { Tidak } \\
\text { memiliki } \\
\text { ventilasi } \\
\text { alami } \\
\text { atau } \\
\text { buatan, } \\
\text { kelemba } \\
\text { ban } \\
\text { kurang } \\
\text { dari 30\% } \\
\text { atau } \\
\text { lebih dari } \\
70 \%\end{array}$} & \multirow[t]{2}{*}{$\begin{array}{l}\text { Memiliki } \\
\text { ventilasi } \\
\text { alami } \\
\text { dengan } \\
\text { bukaan } \\
\text { kurang } \\
\text { dari } 5 \% \text {, } \\
\text { kelemba } \\
\text { ban } 30 \%- \\
70 \%\end{array}$} & \multirow[t]{2}{*}{$\begin{array}{l}\text { Memiliki } \\
\text { ventilasi } \\
\text { alami } \\
\text { dengan } \\
\text { bukaan } \\
\text { s/d } 5 \% \\
\text { dari luas } \\
\text { lantai; } \\
\text { kelemba } \\
\text { ban } \\
35 \%- \\
65 \%\end{array}$} & \multirow[t]{2}{*}{$\begin{array}{l}\text { Memiliki } \\
\text { ventilasi } \\
\text { alami } \\
\text { dengan } \\
\text { bukaan s/d } \\
10 \% \text { dari } \\
\text { luas lantai; } \\
\text { kelembaba } \\
\mathrm{n} \\
\text { kelembaba } \\
\mathrm{n} \\
40 \%-60 \%\end{array}$} & \multirow{2}{*}{$\begin{array}{l}\text { Memiliki } \\
\text { ventilasi } \\
\text { alami } \\
\text { atau } \\
\text { buatan } \\
\text { berupa } \\
\text { bukaan } \\
\text { yang } \\
\text { permane } \\
\text { n dengan } \\
\text { besar } \\
\text { bukaan } \\
>20 \% \\
\text { dari luas } \\
\text { lantai } \\
\text { dan } \\
\text { saling } \\
\text { berhadap } \\
\text { an (cross } \\
\text { ventilatio } \\
n \text { ) } \\
\text { kelemba } \\
\text { ban } \\
40 \% \text { - } \\
60 \%\end{array}$} & $\begin{array}{l}\text { Pasar Kemuning : } \\
\text { Memiliki ventilasi } \\
\text { alami dengan bukaan } \\
\text { s/d } 10 \% \text { dari luas } \\
\text { lantai khususnya di } \\
\text { lantai 1, di lantai } 2 \\
\text { bukaan tidak dapat } \\
\text { melingkupi seluruh } \\
\text { area dagang khususnya } \\
\text { area dagang bagian } \\
\text { tengah ; } \\
\text { kelembaban } \\
65 \%\end{array}$ & $\begin{array}{l}\text { Pasar } \\
\text { Kemuning: } \\
6\end{array}$ & 0,6 \\
\hline & & & & & & $\begin{array}{l}\text { Pasar Dahlia } \\
\text { Memiliki ventilasi } \\
\text { alami dengan bukaan } \\
\text { s/d } 10 \% \text { dari luas } \\
\text { lantai khususnya pada } \\
\text { bagian lantai } 1 \text { dan s/d } \\
5 \% \text { pada bagian lantai } \\
2 ; \\
\text { kelembaban } \\
61 \%\end{array}$ & $\begin{array}{l}\text { Pasar } \\
\text { Dahlia : } 7\end{array}$ & 0,7 \\
\hline & lebih dari & $24+8^{0} \mathrm{C}$ & $24^{\circ} \mathrm{C} \pm 6$ & $24^{\circ} \quad \mathrm{C} \pm$ & $24^{\circ} \mathrm{C} \pm$ & $\begin{array}{l}\text { Pasar Kemuning: } \\
\text { Temperatur rata-rata } \\
\text { dalam ruangan } 32{ }^{\circ} \mathrm{C}\end{array}$ & 3 & 0,3 \\
\hline Temperatur & $24 \pm 8^{0} \mathrm{C}$ & $24 \pm 8 C$ & & $4^{\circ} \mathrm{C}$ & $2^{\circ} \mathrm{C}$ & $\begin{array}{l}\text { Pasar Dahlia : } \\
\text { Temperatur rata-rata } \\
\text { dalam ruangan } 33^{\circ} \mathrm{C}\end{array}$ & 2 & 0,2 \\
\hline \multirow[t]{2}{*}{$\begin{array}{l}\text { Penerangan } \\
\text { (lux) }\end{array}$} & \multirow[b]{2}{*}{$\begin{array}{l} \pm \quad 200 \\
\text { dari nilai } \\
\text { standar }\end{array}$} & \multirow[b]{2}{*}{$\begin{array}{l} \pm \quad 150 \\
\text { dari nilai } \\
\text { standar }\end{array}$} & \multirow[b]{2}{*}{$\begin{array}{l} \pm \quad 100 \\
\text { dari nilai } \\
\text { standar }\end{array}$} & \multirow[b]{2}{*}{$\begin{array}{l} \pm 50 \text { dari } \\
\text { nilai } \\
\text { standar }\end{array}$} & \multirow[b]{2}{*}{$\begin{array}{l}200<\text { Nila } \\
\mathrm{i} \leq 300\end{array}$} & $\begin{array}{l}\text { Pasar Kemuning: Di } \\
\text { lantai } 1 \text { mulai dari } 22 \\
\text { lux sampai dengan } \\
1464 \text { lux. Sedangkan } \\
\text { di lantai } 2 \text { dari } 10 \text { lux } \\
\text { sampai dengan } 4760 \\
\text { lux. Pencahayaan ini } \\
\text { sangat tergantung letak } \\
\text { los/kios. }\end{array}$ & 1 & 0,1 \\
\hline & & & & & & $\begin{array}{l}\text { Pasar Dahlia : } \\
\text { pencahayaan tidak } \\
\text { merata pada bagian- } \\
\text { bagian penjualan. Di } \\
\text { lantai } 1 \text { pencahayaan } \\
\text { mulai kurang dari } 10 \\
\text { lux sampai dengan } \\
2800 \text { lux. Sedangkan } \\
\text { di lantai } 2 \text { dari } 10 \text { lux } \\
\text { sampai dengan } 4000 \\
\text { lux. Pencahayaan ini } \\
\text { sangat tergantung letak } \\
\text { los/kios }\end{array}$ & 1 & 0,1 \\
\hline
\end{tabular}




\section{Persepsi Pengguna terhadap Tingkat Penerangan dan Kenyamanan Udara}

Persepsi pengguna menunjukkan nilai kepuasan dari pengguna terhadap variabel yang diukur. Dari kuesioner berupa skala likert yang telah disebarkan ke pengguna pasar khususnya pembeli dan penjual yang ada di kedua lokasi objek penelitian, hasil penilaia kepuasan dapat terlihat dari nilai yang diberikan pada kuesioner seperti yang ditunjukkan pada gambar2, gambar 3 dan gambar 4 . Gambar 2 menunjukkan nilai-nilai yang dipilih oleh responden terhadap keadaan udara yang dirasakan ketika berada di bangunan pasar. Dari gambar tersebut, terlihat bahwa rata-rata responden memberikan penilaian antar 3 dan 4 dengan standar deviasi 1,96 dari nilai rata-rata. Bangunan pasar Kemuning dan Dahlia mendapat penilaian yang hampir sama oleh responden.

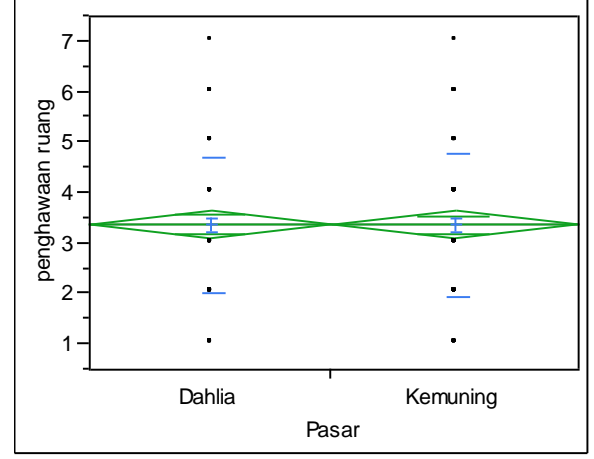

Gambar 2. Penilaian responden terhadap kondisi udara dalam bangunan objek penelitian Sumber: Analisis, 2017

Gambar 3 menunjukkan nilai-nilai yang dipilih oleh responden terhadap kenyamanan temperatur dalam bangunan pasar. Dari gambar tersebut, terlihat bahwa rata-rata responden memberikan untuk penilaian antara 3 dan 4. Bangunan pasar kemuning dan Dahlia mendapat penilaian terhadap kenyamanan temperatur ruang yang hampir sama dari responden.

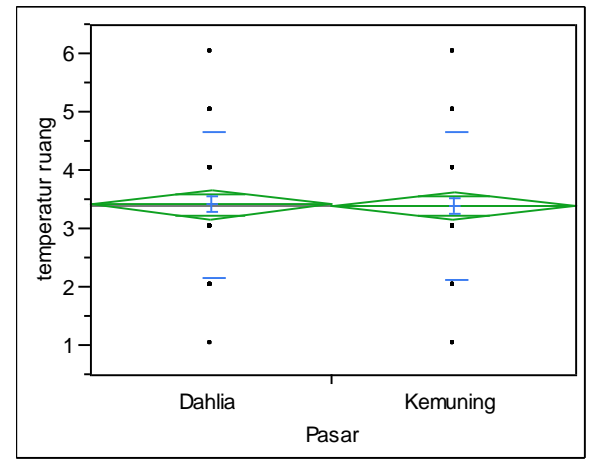

Gambar 3. Penilaian responden terhadap kondisi temperatur ruang dalam bangunan objek penelitian Sumber: Analisis, 2017 


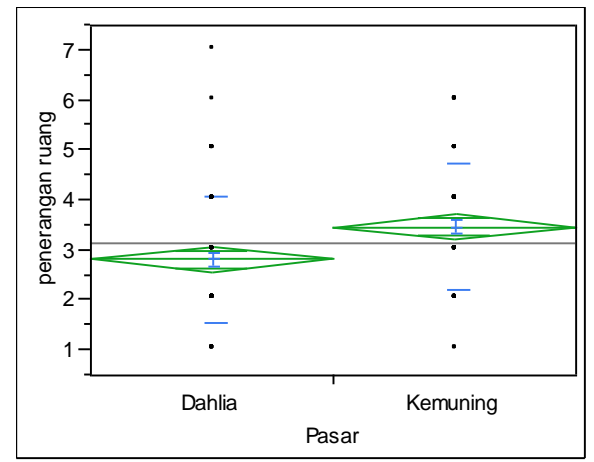

Gambar 4. Penilaian responden terhadap kondisi penerangan ruang dalam bangunan objek penelitian

Sumber. Analisis, 2017

Gambar 4 menunjukkan nilai-nilai yang dipilih oleh responden terhadap kenyamanan penerangan dalam bangunan pasar. Dari gambar tersebut, terlihat bahwa pada bangunan pasar Kemuning, rata-rata penilaian responden berada pada nilai antar 3 dan 4. Sedangkan untuk pasar Dahlia rata-rata penilaian responden terhadap kenyamanan pencahayaan dalam ruang pasar berada pada nilai antar 2 dan 3.

Jika dilihat berdasarkan nilai Responden [NR], maka terlihat seperti tabel 2 dan tabel 3. Nilai Responden [NR] digunakan untuk melihat tingkat kepuasan responden terhadap variabel aspek yang dinilai. Dari kedua tabel tersebut, dapat terlihat bahwa baik pasar Kemuning maupun Dahlia, nilai [NR] untuk kenyamanan udara, temperatur dalam ruang dan tingkat pencahayaan bangunan berada pada nilai 40 sampai dengan 50. Nilai tersebut menunjukkan responden merasa tidak nyaman dengan aspek keadaan udara, temperatur dalam ruang dan tingkat pencahayaan dalam ruang.

Tabel 3. Nilai Responden [NR] Pasar Kemuning

\begin{tabular}{cccc}
\hline \multirow{2}{*}{ Variabel Aspek Bangunan } & \multicolumn{3}{c}{ Kepuasan Responden } \\
\cline { 2 - 4 } & Penjual & Pembeli & Rata-rata \\
\hline Penghawaan & 0,52 & 0,44 & 0,48 \\
\hline Temperatur & 0,49 & 0,48 & 0,49 \\
\hline Penerangan & 0,51 & 0,49 & 0,50 \\
\hline
\end{tabular}

Sumber: Analisis, 2017

Tabel 4. Nilai Responden [NR] Pasar Dahlia

\begin{tabular}{cccc}
\hline \multirow{2}{*}{ Variabel Aspek Bangunan } & \multicolumn{3}{c}{ Kepuasan Responden } \\
\cline { 2 - 4 } & Penjual & Pembeli & Rata-rata \\
\hline Penghawaan & 0,51 & 0,45 & 0,48 \\
\hline Temperatur & 0,51 & 0,46 & 0,49 \\
\hline Penerangan & 0,42 & 0,38 & 0,40 \\
\hline
\end{tabular}

Sumber: Analisis, 2017 
Tabel 5 dan gambar menunjukkan perbandingan antara Nilai Performansi [NP] dan Responden [NR] dari kedua objek pasar yaitu Pasar Kemuning dan Pasar Dahlia. Dari kedua nilai tersebut menunjukkan bahwa aspek kenyamanan udara, temperatur dan pencahayaan dalam ruang masingmasing memiliki nilai yang rendah.

Tabel 5. Perbandingan Nilai Performansi [NP] dan Responden [NR] Pasar Kemuning dan Pasar Dahlia

\begin{tabular}{ccccc}
\hline & \multicolumn{2}{c}{ Pasar Kemuning } & \multicolumn{2}{c}{ Pasar Dahlia } \\
\cline { 2 - 5 } Variabel Aspek bangunan & NR & NP & NR & \multirow{2}{*}{ NP } \\
\hline Penghawaan & 0,48 & 0,60 & 0,48 & 0,70 \\
\hline Temperatur & 0,49 & 0,30 & 0,49 & 0,20 \\
\hline Penerangan & 0,50 & 0,10 & 0,40 & 0,10 \\
\hline
\end{tabular}

Sumber: Analisis, 2017

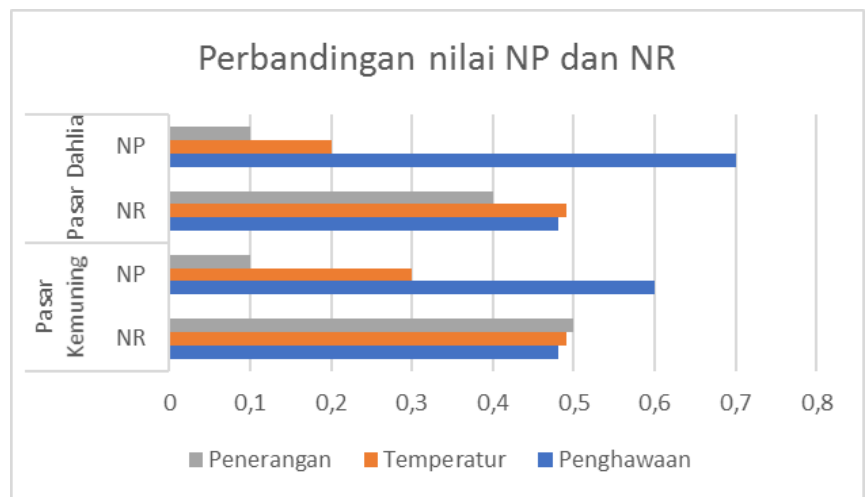

Gambar 5. Perbandingan Nilai Performa dan Nilai Responden Sumber: Analisis, 2017

\section{Kesimpulan}

Isi Berdasarkan penilaian terhadap 3 aspek kenyamanan : kenyamanan udara, temperatur dan pencahayaan dalam ruang pada objek pasar yang diteliti, dapat ditarik beberapa kesimpulan berikut :

1. Kedua bangunan pasar pada umumya telah memiliki bukaan yang cukup besar terlihat dari nilai performanya yang baik, namun penghawaan tidak dirasakan nyaman oleh pengguna, terlihat dari nilai responden yang berada dibawah 0,5 . Hal ini memberikan gambaran bahwa kemungkinan sirkulasi udara belum berjalan dengan baik akibat faktor lain seperti pergerakan angin selain besar bukaan.

2. Pada kedua pasar, nilai performa percahayaan rendah dengan nilai yang sama yaitu 0,1 . Pencahayaan juga dirasakan tidak nyaman oleh pengguna terlihat dari nilai NP yang rendah berada dibawah 0,5 .

3. Pada kedua bangunan pasar masih menunjukkan performa yang kurang baik untuk temperatur ruang maupun pencahayaan dalam ruang. Hal ini ditunjukkan dengan nilai performa yang kurang untuk kedua aspek tersebut dengan nilai performa di bawah 0,5. Pengguna juga merasa tidak nyaman dengan kedua aspek tersebut terlihat dari nilai responden yang berada di bawah nilai 0,5 .

Kedua hasil tersebut dapat memberikan gambaran bahwa desain pasar khususnya untuk aspek pencahayaan dan penghawaan pada kedua pasar belum memberikan nilai kepuasan pada pengguna. Aspek-aspek tersebut perlu diperhatikan untuk meningkatkan performa bangunan tersebut. Perbaikan tingkat pencahayaan sebagai usaha memperbaiki [NP] yang masih rendah pada pasar- 
pasar yang menjadi objek penelitian dapat dilakukan dengan peningkatan kualitas pencahayaan buatan atau memaksimalkan masuknya pencahayaan alami. Bukaan dari bagian lantai atas (pemanfaatan void) perlu dipertimbangkan dalam desain pasar pasar berikutnya, khususnya untuk desain-desain dengan bentuk massa yang cukup lebar. Peningkatan sirkulasi udara dapat dilakukan dengan memperhatikan tinggi bangunan, letak bukaan dan sirkulasi udara yang dapat mendukung pergerakan udara. Tingkat temperatur yang cukup tinggi juga perlu diperhatikan, baik dengan menggunakan penghawaan buatan maupan penghawaan alami melalui desain yang memperhatikan pergerakan angin agar terjadi sirkulasi udara yang cukup baik pada bangunan.

\section{Ucapan Terima Kasih}

Ucapan terimakasih kepada Kementrian Riset, Teknologi dan Pendidikan Tinggi melalui hibah Penelitian Dosen Pemula melalui kontrak 107/SP2H/LT/DRPM/IV/2017 serta Lembaga Penelitian dan Pengabdian Kepada Masyarakat Universitas Tanjungpura

\section{Daftar Pustaka}

Karyono, Tri Harso. (2001). Penelitian Kenyamanan Termis di Jakarta sebagai Acuan Suhu Nyaman Manusia Indonesia. Dimensi Teknik Arsitektur Vol. 29, No. 1. Jurusan Teknik Arsitektur, Fakultas Teknik Sipil dan Perencanaan Universitas Kristen Petra. Surabaya

Keputusan Menteri Kesehatan Republik Indonesia Nomor 1405/Menkes/Sk/Xi/2002 tentang Persyaratan Kesehatan Lingkungan Kerja Perkantoran dan Industri

Keputusan Menteri Kesehatan Republik Indonesia Nomor: 519/Menkes/SK/VI/2008 tentang Pedoman Penyelenggaraan Pasar Sehat

Keputusan Menteri Perdagangan Republik Indonesia Nomor 70/M-DAG/PER/12/2013 tentang Pedoman Penataan dan Pembinaan Pasar Tradisional, Pusat Perbelanjaan dan Toko Modern
Keputusan Menteri Perindustrian dan Perdagangan Nomor 23/MPP/KEP/1/1998 tentang LembagaLembaga Usaha Perdagangan

Peraturan Menteri Pekerjaan Umum Nomor : 29/PRT/M/2006 Tentang Pedoman Persyaratan Teknis Bangunan Gedung

Standar Nasional Indonesia (SNI) 03-6390-2000 tentang Konservasi Energi Sistem Tata Udara pada Bangunan Gedung

Standar Nasional Indonesia (SNI) 8152 - 2015 Tentang Pasar Rakyat

Sukriswanto, Ucang. (2012). Analisis Kelayakan Revitalisasi Pasar Umum Gubug Kabupaten Grobogan. Tesis tidak diterbitkan, Program Studi magister Teknik Sipil, Universitas Diponegoro Semarang.

Undang-Undang Republik Indonesia Nomor 7 tahun 2014 tentang Perdagangan 